\title{
Bis-Amidinium Calixarenes: Templates for Self-Assembled Receptors
}

\author{
Philip A. Gale \\ Chemistry Department, University of Oxford, Inorganic Chemistry Laboratory, South Parks Road, Oxford, OXI 3QR, UK.
}

Received 10 March 1998; accepted 24 March 1998

\begin{abstract}
The synthesis of two bis-amidinium calixarenes 3 and 4 has been achieved. Compounds 3 and 4 selfassemble with carboxylate salts via amidinium-carboxylate salt bridges producing ditopic receptor species.

(C) 1998 Elsevier Science Ltd. All rights reserved.

Keywords: amidines; calixarenes; molecular recognition; complexation.
\end{abstract}

\section{Introduction}

The self-assembly of complex, rationally designed molecular architectures is an area of supramolecular chemistry that has attracted much attention [1]. Less attention has been paid to producing self-assembled 'supermolecules' capable of performing a function such as binding a 'third-party' guest species. Recently, very elegant examples of self-assembled receptors capable of binding anions have been reported by Lehn and coworkers [2] and Stoddart et al. [3].

The amidinium ion forms strong ion pairs in aprotic solvents with oxo-anions [4] and, like guanidinium, is a model system for the arginine-aspartate salt bridge found in zinc finger/DNA complexes, $[5,6]$ RNA stem loops [7] and the active site of dihydrofolate reductase [8]. Amidinium-carboxylate salt bridges have been employed in self-replicating systems [9] and in porphyrin containing molecular arrays designed for the study of electron transfer processes through salt bridges [10]. As part of a new research programme aimed at producing self-assembled receptors for 'third-party' guest species, two new bis-amidinium calixarenes have been synthesised [11]. These species form salt bridges with added carboxylate salts producing supermolecules containing binding sites for other guest species.

\section{Synthesis}

p-tert-Butylcalix[4]arene bis methylene nitrile 1 was synthesised according to literature procedures [12]. para-tert-Butylcalix[4]arene bis- $m$-tolunitrile 2 was synthesised by stirring a slurry of $p$-tert-butylcalix[4]arene with 2.2 equiv. of $\alpha$-bromo- $m$-tolunitrile and potassium carbonate in dry acetone for three days affording the desired bis-substituted calixarene as a white powder in $88 \%$ yield. Garigipati's method of amidine synthesis $[10,13]$, i.e. using alkylchloroaluminium amides (obtained in situ from $\mathrm{Me}_{3} \mathrm{Al}$ and $\mathrm{NH}_{4} \mathrm{Cl}$ ) to convert nitriles to amidinium moieties, was used to produce the new bis-amidinium chloride species 3 and 4 (Scheme 1). The bis-nitrile calixarenes were dissolved in a $0.67 \mathrm{M}$ solution of methylchloroaluminium amide solution in toluene. 
The reaction mixture was heated at $80^{\circ} \mathrm{C}$ for 48 hours and then allowed to cool to room temperature and poured into a slurry of silica in chloroform. The slurry was stirred for 5 minutes and the silica then removed by filtration. The silica plug was washed with dichloromethane and then the combined organic layers reduced in vacuo and purified by column chromatography (silica gel $\mathrm{CH}_{2} \mathrm{Cl}_{2} / \mathrm{MeOH} 8: 2$ ) affording the bis-amidinium species $3^{1}$ and $4^{2}$ in 43 and $24 \%$ respective yields.
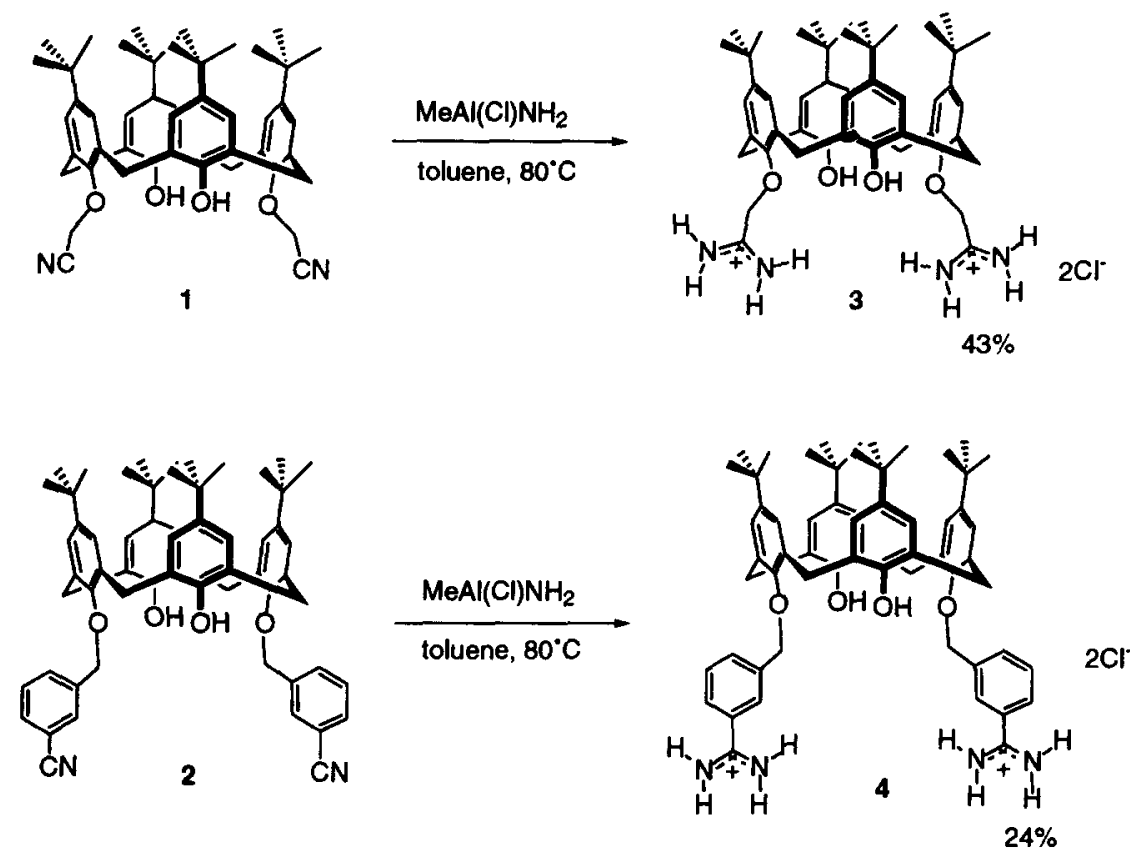

Scheme 1

\section{Spectroscopic Studies: Supermolecule Formation}

The assembly properties of calixarenes 3 and 4 with carboxylate salts have been studied using UV/vis spectroscopic techniques. In a typical experiment, a solution of calixarene $\left(6.5 \times 10^{-5} \mathrm{M}\right)$ was added to a cuvette and the UV/vis spectrum recorded. A solution of a carboxylate salt $\left(2 \times 10^{-3} \mathrm{M}\right)$ in DMSO was then titrated into the cuvette in sub-stoichiometric amounts and the spectrum recorded after each addition. The UV/vis spectra were then processed by the SPECFIT computer program [14]. This allows the number of UV absorbing species in solution and also the stability constants of supermolecules formed to be determined. As expected, in all cases a 2:1 carboxylate : calixarene complex formed in solution. The stability constants for the formation of the assemblies are shown in Table 1 for a variety of carboxylate salts. All the $\log \beta_{2}$ values lie within the range 10.3 - 11.9.

\footnotetext{
${ }^{1}$ Characterization data for 3: $\delta^{1} \mathrm{H}$ NMR (CD $\left.3 \mathrm{OD}, 300 \mathrm{MHz}\right) 7.25(\mathrm{~s}, 4 \mathrm{H}, \mathrm{ArH}), 7.19$ (s, 4H, ArH), 5.07 (s, 4H, OCH $), 4.66(\mathrm{br}$, $\mathrm{m}, 8 \mathrm{H}, \mathrm{NH}), 4.15\left(\mathrm{~d}, \mathrm{~J}=13.5 \mathrm{~Hz}, 4 \mathrm{H}, \mathrm{ArCH}_{2} \mathrm{Ar}\right), 3.59\left(\mathrm{~d}, \mathrm{~J}=13.5 \mathrm{~Hz}, 4 \mathrm{H}, \mathrm{ArCH}_{2} \mathrm{Ar}\right), 3.36,(\mathrm{~s}, 2 \mathrm{H}, \mathrm{OH}), 1.27\left(\mathrm{~s}, 18 \mathrm{H},\left(\mathrm{CH}_{3}\right)_{3} \mathrm{C}\right)$, $1.11\left(\mathrm{~s}, 18 \mathrm{H},\left(\mathrm{CH}_{3}\right)_{3} \mathrm{C}\right) . \delta^{13} \mathrm{C} \mathrm{NMR}\left(\mathrm{CD}_{2} \mathrm{Cl}_{2} / \mathrm{CD}_{3} \mathrm{OD}, 125 \mathrm{MHz}\right): 167.3,150.5,149.3,148.0,144.6,132.8,127.3,126.9,126.7$, 70.8, 34.7, 34.2, 32.2, 31.5, 31.1. High resolution FABMS calc for $\mathrm{C}_{48} \mathrm{H}_{65} \mathrm{~N}_{4} \mathrm{O}_{4}{ }^{+}$(761.5006). Found 761.5007.

${ }^{2}$ Characterization data for 4: $\delta^{1} \mathrm{H}$ NMR $\left(\mathrm{CD}_{2} \mathrm{Cl}_{2}, 300 \mathrm{MHz}\right) 9.19(\mathrm{~s}, 4 \mathrm{H}, \mathrm{NH}), 9.00(\mathrm{~s}, 4 \mathrm{H}, \mathrm{NH}), 8.63(\mathrm{~s}, 2 \mathrm{H}$, tolH), $8.56(\mathrm{~s}, 2 \mathrm{H}$, $\mathrm{OH}), 8.21\left(\mathrm{~m}, 2 \mathrm{H}\right.$, tolH), $8.13(\mathrm{~m}, 2 \mathrm{H}$, tolH $), 7.29(\mathrm{~m}, 2 \mathrm{H}, \mathrm{tolH}) 7.13(\mathrm{~s}, 4 \mathrm{H}, \mathrm{ArH}), 7.11(\mathrm{~s}, 4 \mathrm{H}, \mathrm{ArH}), 5.23\left(\mathrm{~s}, 4 \mathrm{H}, \mathrm{OCH}_{2}\right), 4.35$ (d, J=13.0Hz, 4H, CH$), 3.48\left(\mathrm{~d}, \mathrm{~J}=13.0 \mathrm{~Hz}, 4 \mathrm{H}, \mathrm{CH}_{2}\right), 1.22\left(\mathrm{~s}, 18 \mathrm{H},\left(\mathrm{CH}_{3}\right)_{3} \mathrm{C}\right), 1.17\left(\mathrm{~s}, 18 \mathrm{H},\left(\mathrm{CH}_{3}\right)_{3} \mathrm{C}\right) . \delta^{13} \mathrm{C} \mathrm{NMR}\left(\mathrm{CD}_{2} \mathrm{Cl}_{2}\right.$, $125 \mathrm{MHz}) 165.5,150.0,149.5,148.9,143.6,139.0,133.1,131.9,130.0,128.6,127.7,127.4,126.8,126.2,125.9,77.3,34.6$, 34.1, 32.5, 31.7, 31.3. High resolution FABMS calc for $\mathrm{C}_{60} \mathrm{H}_{73} \mathrm{~N}_{4} \mathrm{O}_{4}+(913.5632)$. Found: 913.5636
} 
Tetrabutylammonium salt

4-nitrobenzoic acid

4-carboxybenzo-15-crown-5

meso-octamethylcalix[4]pyrrole- $\beta$-mono acid [15]
Compound $3\left(\log \beta_{2}\right)$

10.9

11.9

10.5
Compound $4\left(\log \beta_{2}\right)$

11.0

10.5

10.3

\section{Table 1}

Stability constants of carboxylates with compounds 3 and 4 in DMSO (errors are estimated to be $\pm 15 \%$ )

This method also allows the concentration of each species in solution to be determined throughout the titration. This is shown in Figure 1 for compound 3 and tetrabutylammonium 4-carboxybenzo-15-crown-5.

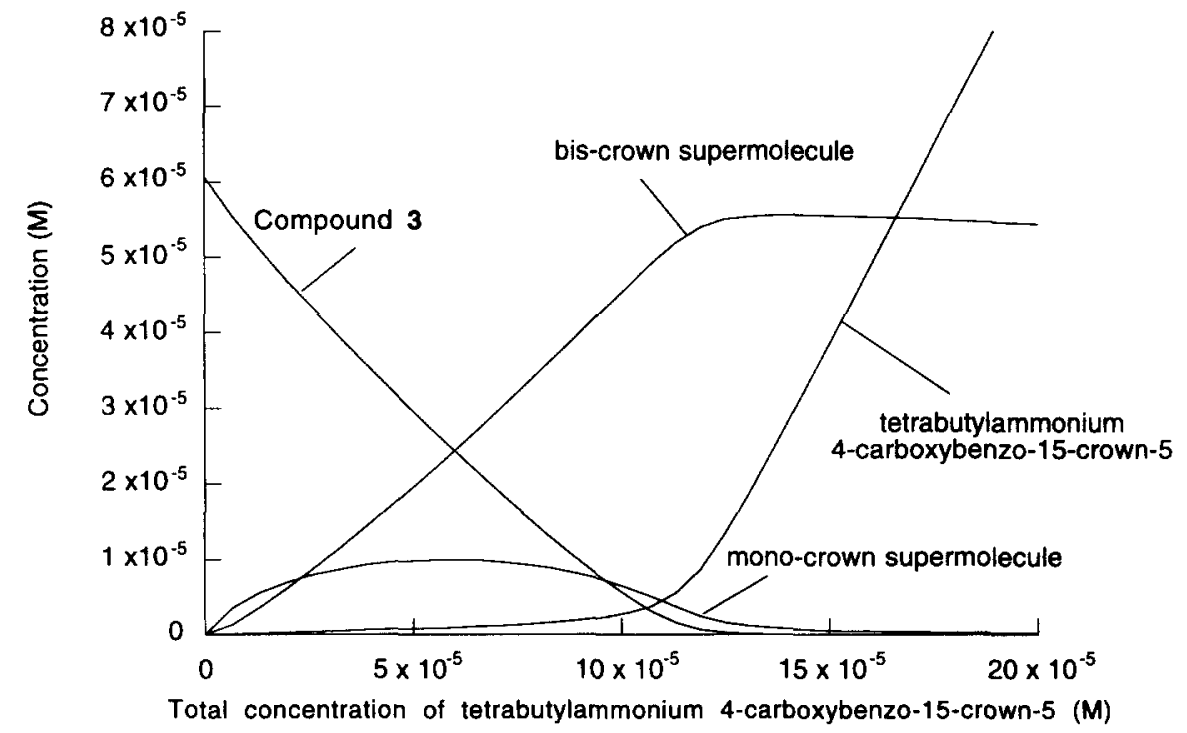

Figure 1

Thus compounds 3 and 4 can be used to assemble ditopic receptor species by mixing with an appropriately functionalised carboxylate (examples are shown in Figure 2). 

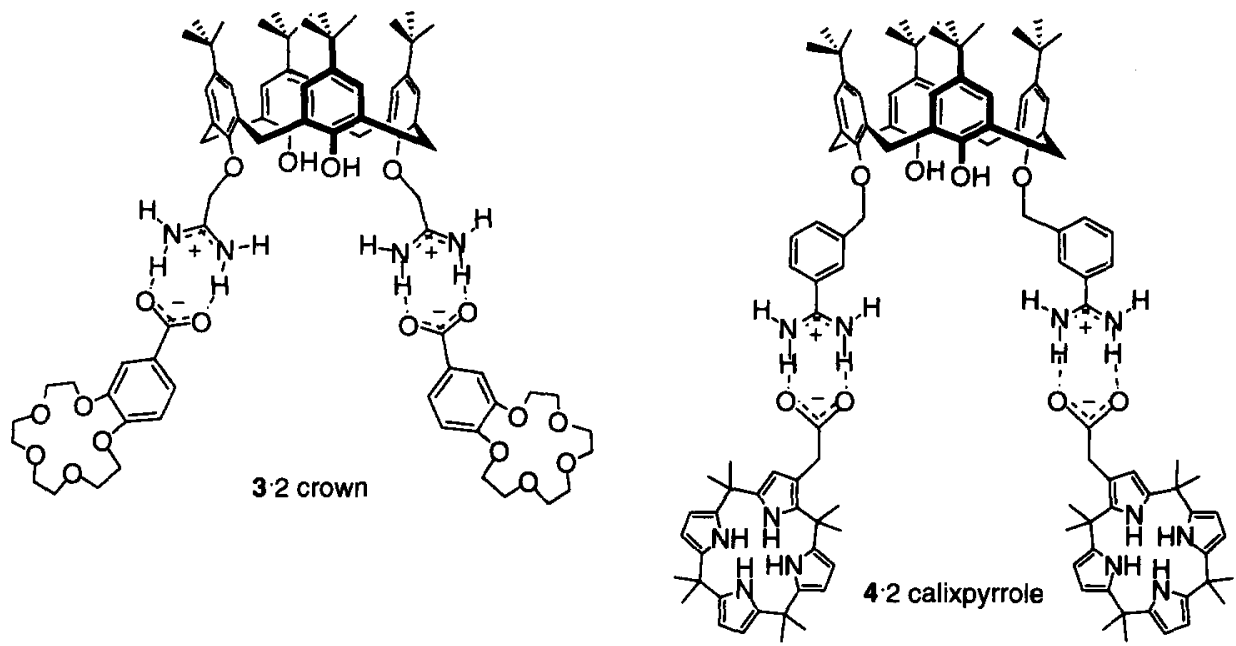

Figure 2

Examples of ditopic supermolecules

\section{Conclusions}

The bis-amidine calixarenes 3 and $\mathbf{4}$ provide access to a wide range of self-assembled structures simply by mixing the calixarene with an appropriate carboxylate. In the case of the examples shown in Figure 2, ditopic cation binding bis-crown ether and anion binding bis-calixpyrrole assemblies have been formed. The coordination chemistry of these non-covalently linked molecular arrays is currently under investigation in the author's laboratory and will be reported in due course.

\section{Acknowledgments}

I would like to thank the Royal Society for the award of a University Research Fellowship

\section{References}

[1] Philp D, Stoddart, JF. Angew. Chem., Int. Ed. Engl. 1996;35;1154.

[2] Hasenknopf B, Lehn J-M, Kneisel BO, Baum G, Fenske D. Angew. Chem. Int. Ed. Engl. 1996;35:1838.

[3] Fyfe MCT, Glink PT, Menzer S, Stoddart JF, White AJP, Williams DJ. Angew. Chem. Int. Ed. Engl. 1996;36:2068

[4] Müller G, Riede J, Schmidtchen FP. Angew. Chem. Int. Ed. Engl. 1988; 27:1516.

[5] Berg JM. Acc. Chem. Res. 1995;28:14.

[6] Pavetich NP, Pabo CO. Science 1991;252:809.

[7] Puglisi JD, Chen L, Frankel AD, Williamson, JR. Proc. Natl. Acad. Sci. USA 1993;90:3680.

[8] Howell EH, Villafranca JE, Warren MS, Oatley SJ, Kraut, J. Science 1986;231:1125.

[9] Terfort A, von Kiedrowski G. Angew. Chem. Int. Ed. Engl. 1992;31:654.

[10] Kirby JP, Roberts JA, Nocera DG. J. Am. Chem. Soc. 1997;119:9230.

[11] For other examples of calixarenes in self-assembley see: Shimizu KD, Rebek J. Proc. Nat. Acad. Sci. USA 1995;92:12403 and Struck O, Verboom W, Smeets WJJ, Spek AL, Reinhoudt DN. J. Chem. Soc. Perkin 2. 1997:223.

[12] Szernes F, Hesek D, Chen Z, Dent SW, Drew MGB, Goulden AJ, Graydon AR, Grieve A, Mortimer RJ, Wear T, Weightman JS, Beer PD. Inorg. Chem. 1996;35:5868.

[13] Garigipati RS, Tetrahedron Lett. 1990; 31:1969.

[14] SPECFIT v 2.10, Spectrum Software Associates, Chapel Hill, NC, USA.

[15] Sessler JL, Gale PA, Genge JW. Chem. Eur. J. in press. 